\title{
Variations in snowpack melt on the Greenland ice sheet based on passive-microwave measurements
}

\author{
Thomas L. Mote \\ Department of Geography, University of Georgia, Athens, GA 30602-2502, U.S.A. \\ MARK R. ANDERSON \\ Program in Meteorology/Climatology, Department of Geography, University of Nebraska-Lincoln, \\ Lincoln, NE 68588-0135, U.S.A.
}

\begin{abstract}
A simple microwave-emission model is used to simulate $37 \mathrm{GHz}$ brightness temperatures associated with snowpack-melt conditions for locations across the Greenland ice sheet. The simulated values are utilized as threshold values and compared to daily, gridded SMMR and SSM/I passive-microwave data, in order to reveal regions experiencing melt. The spatial extent of the area classified as melting is examined on a daily, monthly and seasonal (May-August) basis for 1979 91. The typical seasonal cycle of melt coverage shows melt beginning in late April, a rapid increase in the melting area from mid-May to mid-July, a rapid decrease in melt extent from late July through mid-August, and cessation of melt in late September. Seasonal averages of the daily melt extents demonstrate an apparent increase in melt coverage over the 13 year period of approximately $3.8 \%$ annually (significant at the $95 \%$ confidence interval). This increase is dominated by statistically significant positive trends in melt coverage during July and August in the west and southwest of the ice sheet. We find that a linear correlation between microwave-derived melt extent and a surface measure of ablation rate is significant in June and July but not August, so caution must be exercised in using the microwave-derived melt extents in August. Nevertheless, knowledge of the variability of snowpack melt on the Greenland ice sheet as derived from microwave data should prove useful in detecting climate change in the Arctic and examining the impact of climate change on the ice sheet.
\end{abstract}

\section{INTRODUCTION}

Scientific interest in the magnitude of melting on the Greenland and Antarctic ice sheets has grown along with concern about the potential effects of climate change. In particular, increased melting in a warmer climate may lead to rising sea levels (Bindschadler, 1985; Peltier and Tushingham, 1989). However, Zwally (1989) found that the ablation and accumulation zones of the Greenland ice sheet thickened between 1978 and 1985, as determined from radar-altimetry data, and suggested the change might be a product of increased accumulation associated with a warmer climate. This reasoning also suggests that increased melting should be associated with, but more than offset by, the increased accumulation. In contrast, Braithwaite and others (1992) used stake observations at three locations near the margin of the ice sheet to argue that thickening in the ablation zone was due to decreased ablation, primarily from decreased melting.

The question of how the ice sheet responds to variations in climate, and potential climate change, can be addressed at least partially by examining the variations in snowpack melt. Unfortunately, identification of snowpack-melt events on the Greenland ice sheet is accomplished only at a few isolated stations or by interpretation of shallow-ice-core records that are widely scattered. Satellite remote sensing offers a means of acquiring a spatially and temporally detailed record of snowpack-melt occurrences. Passive-microwave remote sensing is especially suited to measuring melt occurrences due to the rapid change in microwave emission of a snowpack in response to the introduction of even a small amount of liquid water. Microwave emission, as described by a blackbody-equivalent radiometric temperature called a brightness temperature $\left(T_{\mathrm{B}}\right)$, exhibits a distinct increase at frequencies greater than $10 \mathrm{GHz}$ during snowpack melt in the West Greenland percolation zone (Thomas and others, 1985). This increase in $T_{\mathrm{B}}$ stands in sharp contrast to the lower $T_{\mathrm{B}}$ observed during non-melt conditions (Gloersen and others, 1974) due to internal scattering within the snowpack (Zwally, 1977). The emissivity of snow changes rapidly with melt due to an increase in the liquid-water content of the snow. Because of the high dielectric constant of liquid water compared to that of air and ice, melt strongly affects the dielectric constant of the ice-air-water mixture (Ulaby and others, 1986). The increase in the dielectric constant raises the absorptivity and, according to Kirchoff's law, the 
emissivity. The result is an increase in absorption relative to volume scattering, which reduces the scattering albedo and enhances emission (Chang and others, 1976, 1985; Foster and others, 1984).

This change in $T_{\mathrm{B}}$ with melt is frequency-dependent. Below approximately $10 \mathrm{GHz}$, a spectral region where volume scattering is small compared to surface scattering, the $T_{\mathrm{B}}$ decreases with increasing liquid-water content; near $10 \mathrm{GHz}$, the $T_{\mathrm{B}}$ is nearly insensitive to liquid-water content (Ulaby and others, 1986). The $T_{\mathrm{B}}$ becomes increasingly sensitive to water content at higher frequencies. The frequency dependence of the $T_{\mathrm{B}}$ on liquid-water content has been used to identify the onset of melt in the seasonal snowpack. Kunzi and others (1982) found the $37 \mathrm{GHz} T_{\mathrm{B}}$ to be lower than the $18 \mathrm{GHz} T_{\mathrm{B}}$ of dry snow, but the two values are nearly equal for wet snow. Other investigators have relied on the increase in brightness temperatures at high frequencies $(37 \mathrm{GHz})$ to identify melt and quantify the liquid-water content of the snowpack (e.g. Stiles and Ulaby, 1980).

Although snow density, temperature, crystal structure and crystal size all contribute to the snowpack's emissivity, changes in the liquid-water content produce the most prominent changes in $T_{\mathrm{B}}$. For example, snow with $2 \%$ liquid-water content may produce a $37 \mathrm{GHz} T_{\mathrm{B}}$ more than $100 \mathrm{deg}$ higher than dry snow (Hofer and Matzler, 1980). The increase in $T_{\mathrm{B}}$ with melt was used to map regions of the Greenland ice sheet experiencing melt during a period of intense warming in 1989 (Mote and others, 1993). As a continuation of that research, we use the increase in $T_{\mathrm{B}}$ at $37 \mathrm{GHz}$ to quantify the extent and frequency of melt on the Greenland ice sheet during the period 1979-91.

\section{SATELLITE MICROWAVE DATA}

Measurements of snowpack melt were made using data obtained from two satellite microwave radiometers, the Nimbus-7 Scanning Multichannel Microwave Radiometer (SMMR) and the Defense Meteorological Satellite Program (DMSP) Special Sensor Microwave/Imager (SSM/I). The SMMR recorded radiation every other day in ten channels (Gloersen and Hardis, 1978), including both polarizations for $6.6,10.7,18.0,21.0$ and $37.0 \mathrm{GHz}$, from October 1978 to August 1987. The SSM/I, which began operation in July 1987 , records radiation daily in seven channels, the vertical polarization for $22.2 \mathrm{GHz}$ and both polarizations for 19.35, 37.0 and $85.5 \mathrm{GHz}$ (Hollinger and others, 1987). The $37 \mathrm{GHz}$, horizontally polarized $(37 \mathrm{H})$ channel was used for this research due to the great sensitivity of that channel to changes in snowpack liquid-water content. Additionally, the $37 \mathrm{H}$ channel had the smallest relative calibration difference between the two sensors, which facilitates merging the two data sets (Jezek and others, 1991).

The two sensors differ in view angle $\left(50.3^{\circ}\right.$ for SMMR vs $53.1^{\circ}$ for $\mathrm{SSM} / \mathrm{I}$ ), radiometric resolution and calibration. Due to a change in swath width (approximately $1400 \mathrm{~km}$ for SSM/I vs $700 \mathrm{~km}$ for SMMR), the number of daily overpasses of a given location is greater for the SSM/ I than for the SMMR. A systematic difference in SMMR and SSM/I brightness temperatures is primarily due to the difference in calibration of the two sensors (Jezek and others, 1991). A linear regression of the brightness temperatures was used to remove this systematic difference. The regression was performed using daily, gridded SSM/I and SMMR brightness temperatures for locations north of $70^{\circ} \mathrm{N}$ and at elevations greater than $2700 \mathrm{~m}$ a.s.l. This region, which approximates the drysnow zone of the ice sheet, was selected to avoid the influence of melt on the regression. Data for $20 \mathrm{~d}$ between 11 July and 20 August 1987, the period when both sensors were operating concurrently, were included in the regression. The resulting equation for the $37 \mathrm{H}$ channel $\left(r^{2}=0.97\right)$ is:

$$
T_{\mathrm{B}, \mathrm{SSMI}}=1.084 T_{\mathrm{B}, \mathrm{SMMR}}-10.81
$$

where $T_{\mathrm{B}, \mathrm{SMMR}}$ is the SMMR brightness temperature $(\mathrm{K})$ and $T_{\mathrm{B}, \mathrm{SSMI}}$ is the $\mathrm{SSM} / \mathrm{I}$ brightness temperature $(\mathrm{K})$. All SMMR brightness temperatures were converted to equivalent SSM/I brightness temperatures using this regression equation.

The SMMR and SSM/I data were obtained from the National Snow and Ice Data Center (NSIDC) archive of brightness-temperature grids. The orbital data were interpolated onto a $25 \mathrm{~km} \times 25 \mathrm{~km}$ grid on a polar stereographic projection. Any data sample located within a given grid cell on a given day, beginning at 0 Coordinated Universal Time (UTC), was averaged into the daily value for that grid cell (NSIDC, 1992). Grid cells with missing data were filled by spatially averaging the grid cells immediately adjacent. Seven days that are included in the NSIDC archive were eliminated from the analysis because of missing swaths of data.

A land mask was digitized from the Quaternary map of Greenland published by The Geological Survey of Greenland. This mask was used in conjunction with both the SMMR and SSM/I water and coastline masks to eliminate any grid cells not covered by at least $50 \%$ ice or with any permanently standing water. The unmasked grid cells available for analysis covered a total area of $1648125 \mathrm{~km}^{2}$, including parts of ice caps separate from the ice sheet. The ice sheet covers approximately $1701000 \mathrm{~km}^{2}$ and ice caps cover another $65000 \mathrm{~km}^{2}$ (Weidick, 1985). Between $7 \%$ and $12 \%$ of the ice sheet and ice caps is removed from the analysis by the masking process.

\section{MICROWAVE EMISSION OF MELTING SNOW}

A simple microwave-emission model was employed to determine the $37 \mathrm{H} \quad T_{\mathrm{B}}$ associated with snow cover containing a given volumetric water content $\left(m_{\mathrm{V}}\right)$ for each grid cell on the Greenland ice sheet. Because $T_{\mathrm{B}}$ increases with increasing $m_{\mathrm{v}}$, a simulated $T_{\mathrm{B}}$ can be used as a threshold value to identify the occurrence of snowpack melt with microwave data. Given the lack of data on snow grain-size and density necessary for calculation of scattering coefficients, a semi-empirical approach was taken in which the emission model was first inverted under non-melt conditions to derive scattering coefficients. Ulaby and Stiles (1980) give the brightness temperature $\left(T_{\mathrm{si}}\right)$ produced by the $i$ th snow layer of thickness $d_{\mathrm{i}}$ as: 


$$
\begin{aligned}
T_{\mathrm{si}}=T_{i} \int_{0}^{d_{\mathrm{i}}} \rho_{\mathrm{i}} \kappa_{\mathrm{ai}}^{\prime} \sec \theta_{\mathrm{i}}^{\prime} \\
\quad \exp \left[-\left(\kappa_{\mathrm{ai}}^{\prime}+\kappa_{\mathrm{si}}^{\prime}\right) \rho_{\mathrm{i}}\left(d_{\mathrm{i}}-h\right) \sec \theta_{\mathrm{i}}^{\prime}\right] \mathrm{d} h
\end{aligned}
$$

where $T_{i}$ is the thermometric temperature of layer $i(\mathrm{~K})$, $\kappa_{\mathrm{ai}}^{\prime}$ is the mass absorption coefficient $\left(\mathrm{kg}^{-1} \mathrm{~m}^{3}\right), \kappa_{\mathrm{si}}^{\prime}$ is the mass scattering coefficient $\left(\mathrm{kg}^{-1} \mathrm{~m}^{3}\right), \theta_{\mathrm{i}}^{\prime}$ is the propagation angle, $h$ is the depth in the $i$ th layer $(\mathrm{m})$, and $\rho_{\mathrm{i}}$ is the density $\left(\mathrm{kg} \mathrm{m}^{-3}\right)$. The integral can be solved analytically and expanded for multiple snow layers, ignoring diffuse scatter and multiple reflections at boundary layers, to determine the brightness temperature at the surface of the snowpack $\left(T_{\mathrm{B}}^{\prime}\right.$ ) (Abdelrazik and others, 1981). The $T_{\mathrm{B}}$ detected by the satellite sensor is the sum of $T_{\mathrm{B}}^{\prime}$, upwelling sky radiation, reflected downwelling sky radiation, and the reflected emission from free space, and is found by:

$$
\begin{aligned}
T_{\mathrm{B}}= & T_{\mathrm{B}}^{\prime} \mathrm{e}^{-\tau \sec \theta}+T_{\text {sky }}+(1-\epsilon) T_{\text {sky }} \mathrm{e}^{-\tau \sec \theta} \\
& +(1-\epsilon) T_{\mathrm{sp}} \mathrm{e}^{-2 \tau \sec \theta}
\end{aligned}
$$

where $T_{\text {sky }}$ is the sky brightness temperature at $37 \mathrm{GHz}$ $(25 \mathrm{~K}), T_{\mathrm{sp}}$ is the averaged brightness temperature of free space $(3 \mathrm{~K}), \tau$ is the atmospheric loss factor at $37 \mathrm{GHz}$ (0.05), $\theta$ is the sensor view angle, and $\epsilon$ is the bulk emissivity of the snowpack.

The increase in microwave emission of snow undergoing melt is associated with an increase in the absorption coefficient. Therefore, the absorption coefficient must be calculated under spring pre-melt and summer-melt conditions. The absorption coefficient can be found by:

$$
\kappa_{\mathrm{a}}=4 \pi / \lambda\left[k_{\mathrm{s}}^{\prime} / 2\left(\left[1+\left(k_{\mathrm{s}}^{\prime \prime} / k_{\mathrm{s}}^{\prime}\right)^{2}\right]^{0.5}\right)-1\right]^{0.5}
$$

where $\kappa_{\mathrm{a}}$ is the absorption coefficient $\left(\mathrm{m}^{-1}\right), \lambda$ is the wavelength $(\mathrm{m}), k_{\mathrm{s}}^{\prime}$ is the real part of the dielectric constant of snow, and $k^{\prime \prime}{ }_{\mathrm{s}}$ is the imaginary part of the dielectric constant.

The complex dielectric constant of snow was calculated using a dielectric mixing model from Tinga and others (1973), which has been used to determine the dielectric properties of snow undergoing melt (Tiuri and Schultz, 1980). The complex dielectric constant can be found by:

$$
\begin{aligned}
k_{\mathrm{s}}= & 3\left[a\left(r_{\mathrm{w}} / r_{\mathrm{a}}\right)^{3}\left(k_{\mathrm{w}}-1\right)\right. \\
& \left.-b\left(r_{\mathrm{i}} / r_{\mathrm{a}}\right)^{3}\left(2 k_{\mathrm{w}}+1\right)\right] \\
& /\left[a\left(2+k_{\mathrm{w}}\right)-2 b\left(r_{\mathrm{i}} / r_{\mathrm{w}}\right)^{3}\left(k_{\mathrm{w}}-1\right)\right. \\
& -a\left(r_{\mathrm{w}} / r_{\mathrm{a}}\right)^{3}\left(k_{\mathrm{w}}-1\right)+b\left(r_{\mathrm{i}} / r_{\mathrm{a}}\right)^{3} \\
& \left.\left(2 k_{\mathrm{w}}+1\right)\right]+1 \\
a= & 2 k_{\mathrm{w}}+k_{\mathrm{i}} \\
b= & k_{\mathrm{w}}-k_{\mathrm{i}} \\
r_{\mathrm{w}}= & r_{\mathrm{i}}\left[1+\frac{0.92 m_{\mathrm{v}} / \rho_{\mathrm{s}}}{1-\left(m_{\mathrm{v}} / \rho_{\mathrm{s}}\right)}\right]^{\frac{1}{3}} \\
r_{\mathrm{a}}= & r_{\mathrm{i}}\left[\frac{0.92}{\rho_{\mathrm{s}}}\right]^{\frac{1}{3}}\left[1+\frac{m_{\mathrm{v}} / \rho_{\mathrm{s}}}{1-m_{\mathrm{v}} / \rho_{\mathrm{s}}}\right]^{\frac{1}{3}}
\end{aligned}
$$

where $k_{\mathrm{s}}$ is the complex dielectric constant of snow, $k_{\mathrm{w}}$ is the complex dielectric constant of water, $k_{\mathrm{i}}$ is the complex dielectric constant of ice, $r_{\mathrm{i}}$ is the radius of ice particles $(\mathrm{m}), r_{\mathrm{a}}$ is the radius of air pockets $(\mathrm{m}), r_{\mathrm{w}}$ is the radius of water-covered ice particles $(\mathrm{m}), m_{\mathrm{v}}$ is the volumetric water content, and $\rho_{\mathrm{s}}$ is the density of snow $\left(\mathrm{kg} \mathrm{m}^{-3}\right)$. Smooth boundaries between snow layers and at the snowair boundary were assumed, and the transmission coefficients at each boundary were calculated by:

$$
\tau_{\mathrm{s}}=1-\left[\frac{\left(\cos \theta_{\mathrm{t}}-\sqrt{\epsilon_{b} / \epsilon_{t}-\sin ^{2} \theta_{\mathrm{t}}}\right)}{\left(\cos \theta_{\mathrm{t}}+\sqrt{\epsilon_{b} / \epsilon_{t}-\sin ^{2} \theta_{\mathrm{t}}}\right)}\right]^{2}
$$

where $\tau_{\mathrm{s}}$ is the power transmission coefficient, $\epsilon_{\mathrm{b}}$ is the relative dielectric of the underlying layer, $\epsilon_{\mathrm{t}}$ is the relative dielectric of the overlying layer, and $\theta_{\mathrm{t}}$ is the propagation angle.

The model was first inverted under spring conditions to calculate scattering coefficients for each year. Scattering coefficients were estimated for individual years to account for differences in the amount of winter accumulation, which may affect the scattering properties of the snow. Observed brightness temperatures were averaged for a period before the onset of summer melt and used in the model to calculate scattering coefficients. The observed brightness temperatures were averaged for a period in each year when the temperature profile is assumed to have been nearly isothermal, and just prior to the onset of melt. This allows estimated $10 \mathrm{~m}$ temperatures to be used to approximate the temperature throughout the snowpack. Based on these criteria, the first $15 \mathrm{~d}$ of April were selected as the most appropriate period for using the observed brightness temperatures to estimate scattering coefficients.

The $10 \mathrm{~m}$ snowpack temperature for each grid cell was estimated from a third-order regression equation based on latitude, longitude and elevation (Budd and others, 1982). Elevation data were from the radar altimeter aboard ERS-1 (personal communication from S. Ekholm, 1993) and from the Seasat radar altimeter (Bindschadler and others, 1989).

Absorption coefficients were based on a snowpack density of $480 \mathrm{~kg} \mathrm{~m}^{-3}$, typical conditions for the top meter of moderately packed snow (Zwally, 1977), and a mean grain-size of $0.5 \mathrm{~mm}$, which is appropriate for fine-grained snow (Stephenson, 1967). Changing the grain-size does not strongly affect the simulated brightness temperatures. The spatial variation in grain-size should be accounted for by the empirically derived scattering coefficients.

Using the empirically derived scattering coefficients, summer-melt conditions were simulated by the addition of $1 \%$ liquid water to the top $1 \mathrm{~m}$ of the snowpack. The $1 \%$ value was chosen because it is near the lower limit of the radiometer's sensitivity to changes in water content (Stiles and Ulaby, 1980). The thermometric temperature of the top $1 \mathrm{~m}$ was assumed to be $273 \mathrm{~K}$. The model does not account for changes in the scattering coefficient due to grain growth associated with the freeze-thaw metamorphism of melt. Estimated rates of grain growth were initially incorporated into the model, and a linear increase in the scattering coefficient with grain growth was assumed, as suggested by Rotman and others (1982), 
but these changes had little effect on the simulated-melt $T_{\mathrm{B}}$. Because of the limited knowledge of grain-size distributions on the ice sheet, the results presented here do not include a correction to the scattering coefficient for grain growth.

A map of the mean simulated-melt brightness temperatures for the 13 years (Fig. 1) generally resembles that of the mean-emissivity map for April (Fig. 2). The emissivity map was produced from observed April brightness temperatures and $10 \mathrm{~m}$ snowpack temperatures using the Rayleigh-Jeans approximation, which states:

$$
\epsilon=\frac{T_{\mathrm{B}}}{T}
$$

where $\epsilon$ is the emissivity, and $T$ is the thermometric temperature. The relationships between the simulatedmelt $T_{\mathrm{B}}$ and both the observed April $T_{\mathrm{B}}$ and April emissivity are not linear. The relatively warm underlying snowpack in the southwest results in simulated-melt $T_{\mathrm{B}}$ higher than would be expected from a simple linear relationship with the April emissivity. Conversely, the

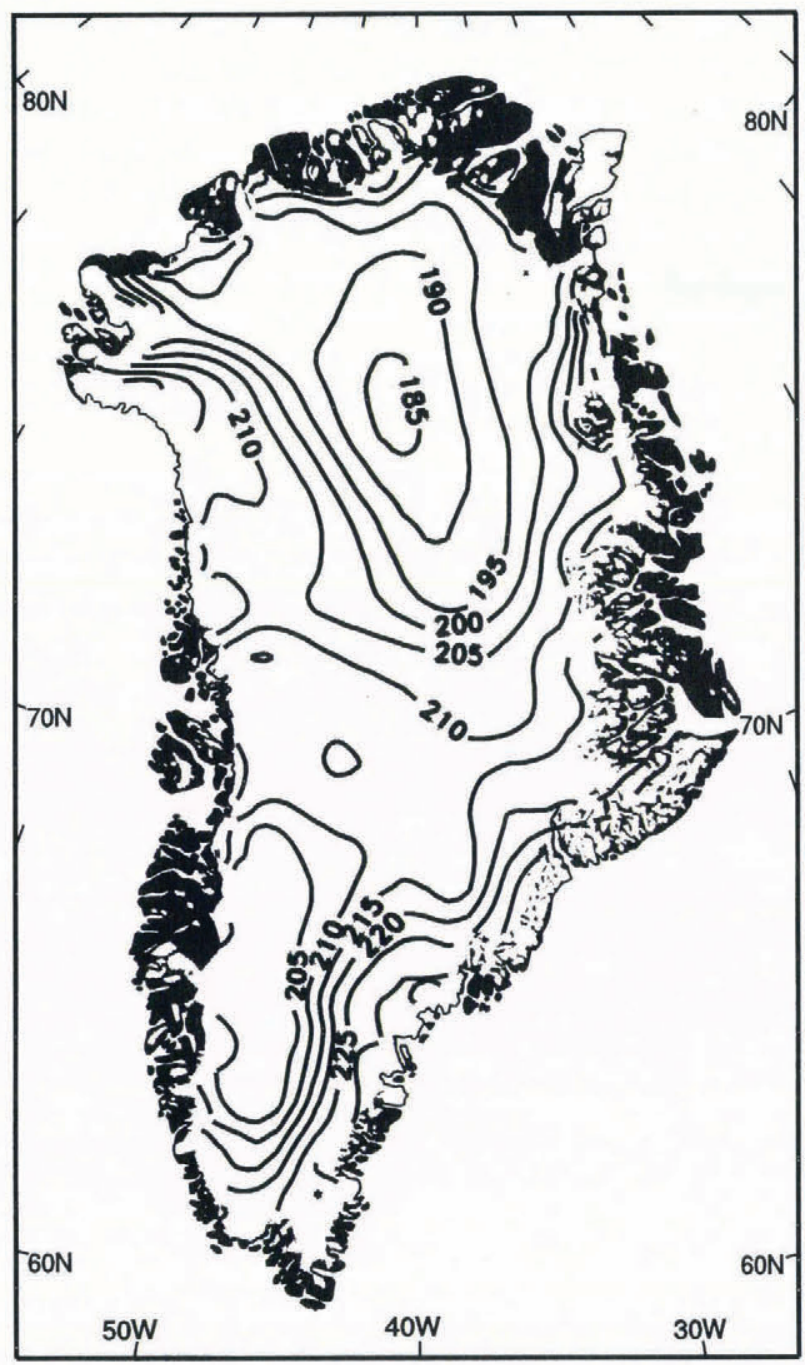

Fig. 1. Mean values of the simulated $37 \mathrm{GHz}$ brightness temperatures associated with summer-melt conditions for each year 1979-91. The brightness temperatures for each year are calculated from a simple microwave-emission model of the snowpack with $1 \%$ liquid-water content.

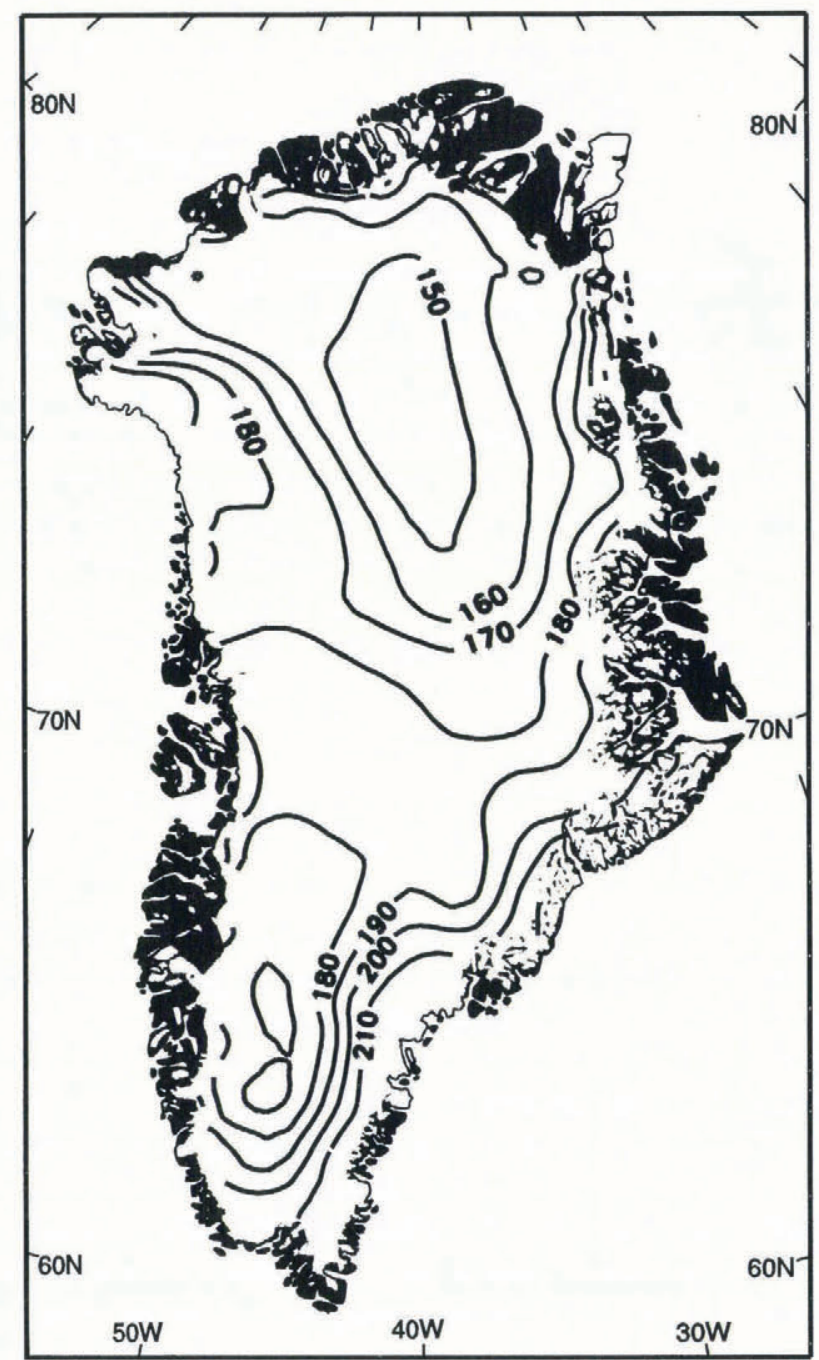

Fig. 2. Mean April microwave emissivities at $37 \mathrm{GHz}$ determined from observed April brightness temperatures and estimated $10 \mathrm{~m}$ firn temperatures.

cold underlying snowpack in the far north results in simulated-melt $T_{\mathrm{B}}$ lower than would be expected based on the April emissivity. Additionally, the high spring emissivities in the southeast, in some cases near 0.85 , do not increase substantially during the simulated melt. In some locations in the southeast, the simulated-melt $T_{\mathrm{B}}$ is less than $15 \mathrm{deg}$ greater than the mean observed April $T_{\mathrm{B}}$, compared to differences of $30 \mathrm{deg}$ in the southwest (Fig. 3).

The use of a modeled threshold $T_{\mathrm{B}}$ for each grid cell as a means of identifying melt is an improvement over the uniform step change in $T_{\mathrm{B}}$ for all grid cells used by Mote and others (1993). The use of a $31 \mathrm{deg}$ change from observed January values in $T_{\mathrm{B}}$ to identify melt resulted in threshold brightness temperatures near $273 \mathrm{~K}$ at some locations along the southeast margin of the ice sheet. Observed brightness temperatures in this region seldom exceed $265 \mathrm{~K}$, although melt is known to occur here.

The general patterns evident in both the simulatedmelt $T_{\mathrm{B}}$ (Fig. 1) and April-emissivity (Fig. 2) maps result from variations in the accumulation rate across the ice sheet. The April-emissivity map (Fig. 2) closely resembles the latest accumulation map for Greenland (Ohmura and Reeh, 1991). Rotman and others (1982) demonstrated that accumulation rates could be determined from 


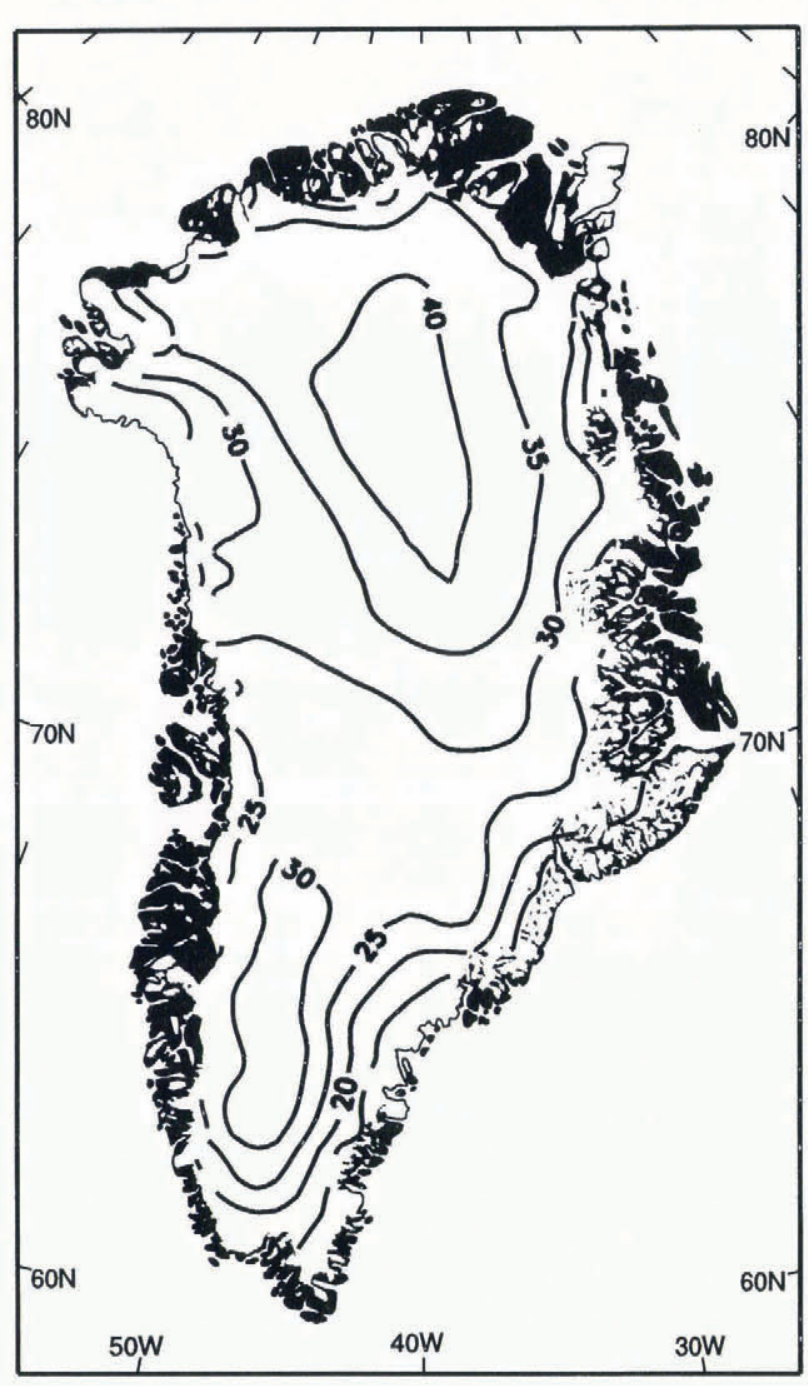

Fig. 3. Simulated summer-melt $37 \mathrm{GHz}$ brightness temperatures minus mean observed brightness temperatures for April 1979-91.

microwave emissivities for the dry-snow zone of the Greenland ice sheet. The southeast of the ice sheet experiences much higher emissions than the southwest (Fig. 2). This difference is due to increased accumulation in the southeast from the orographic lifting of moist air by the Icelandic low (Ohmura and Reeh, 1991). The microwave emissivity of the southwest is much lower due to lower accumulation rates. The regions of higher accumulation near the ice margin at $77^{\circ} \mathrm{N}$ and at 1500 $2400 \mathrm{~m}$ a.s.l. from $69^{\circ} \mathrm{N}$ to $72^{\circ} \mathrm{N}$, as identified by Ohmura and Reeh (1991), are also evident as regions of higher emissivity (Fig. 2).

\section{AREAL MELT EXTENT}

Values of the $37 \mathrm{GHz}$, horizontally polarized brightness temperatures for each day of available data were compared to the simulated-melt brightness temperatures for the given year. The simulated values for each year were used as threshold values to identify whether the snowpack in a given grid cell was experiencing melt. The spatial coverage of grid cells identified as experiencing melt each day was summed to quantify the areal extent of melt. The daily melt extents were then averaged on a monthly and seasonal (May-August) basis to produce mean monthly and mean seasonal melt extents. The mean melt extents are analogous to the average frequency of melt occurrence of all grid cells for a given month or season. This measurement does not indicate the intensity of the melt occurring in a grid cell on any given day. However, the climatic conditions averaged over months and seasons that produce intensive melt should usually be associated with more extensive and more frequent melt.

To merge the two data sets, the melt extents derived from each sensor for the period when both were operating (11 July-20 August 1987) are compared to determine the magnitude of error introduced by the sensor change. The comparison is made with and without the conversion of SMMR brightness temperatures using the linear regression of SMMR and SSM/I brightness temperatures. The mean melt extent detected by SMMR during the $20 \mathrm{~d}$ when both sensors were operating, after the conversion had been applied, is approximately $2.5 \%$ more than that detected by $\mathrm{SSM} / \mathrm{I}$. This compares favorably to a $19 \%$ greater melt area detected by SSM/I without the conversion. With the conversion applied, the SSM/I identifies more melt on the two days of greatest melt extent, but the SMMR identifies more melt on two-thirds of the remaining days (Fig. 4). Examination of the spatial pattern of the difference in melt frequency identified by the two sensors evidences no regional bias. After the conversion is applied, the differences in melt frequency appear to be randomly distributed. The remaining differences are likely produced by the variation in the time of overpass for each sensor. The liquid water content has a strong diurnal cycle, and as a result, the $T_{\mathrm{B}}$ is also a function of the time of day during melt.

In order to determine how well the microwave data can be used to represent changes in the surface climate of

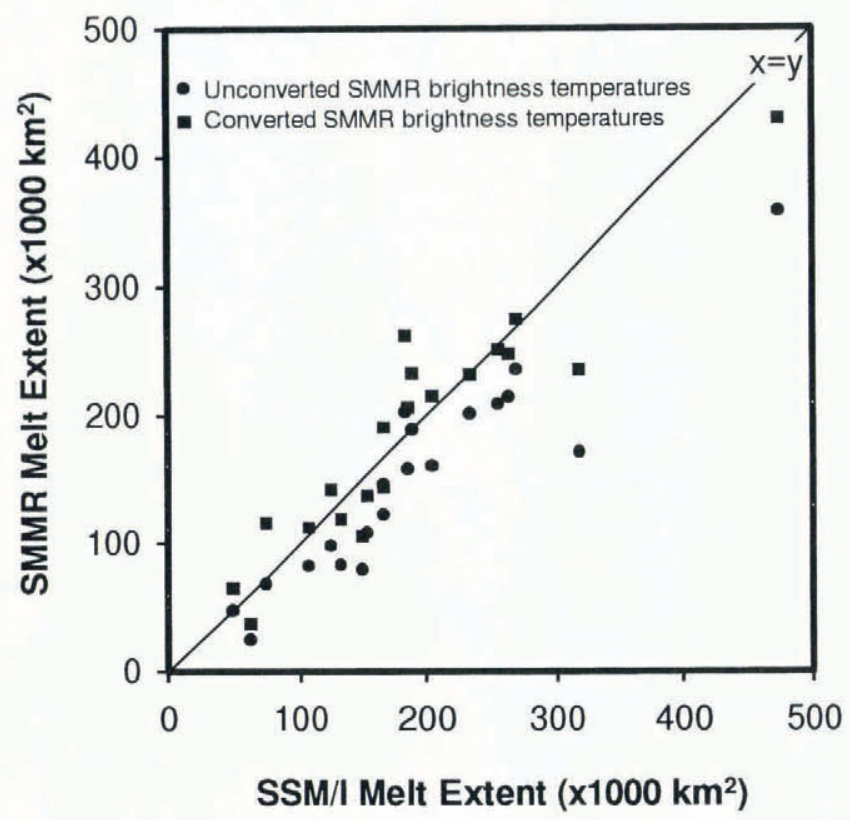

Fig. 4. Daily melt area identified in July and August 1987 with SSM/I data vs the melt area identified by SMMR data before and after a conversion of the SMMR data to account for calibration differences between the two sensors. 
the ice sheet, the microwave-derived melt-extent time series was compared to the ablation rate measured at Qamanârssûp sermia. Braithwaite and Olesen (1990) published monthly values of the ablation rate at Qamanârssûp sermia $\left(64^{\circ} 28^{\prime} \mathrm{N}\right)$, which were taken from a stake measurement at $790 \mathrm{~m}$ a.s.l. The ablation data were compared to the mean melt extent for each month for a region of the ice sheet that includes Qamanârssûp sermia. The ice sheet was divided into eight regions (Fig. $5)$, defined by topographic barriers that limit the transport of moisture, as shown by Ohmura and Reeh (1991). Monthly mean melt extents were calculated for each region. The ablation rate for Qamanârssûp sermia was compared to the monthly mean melt extent for Region 2. The topographic barriers that define each of these regions should serve as a barrier to sensible heat advection as well as moisture advection. As a result, changes in atmospheric circulation should have a distinctly different effect on melt occurrence in each of these regions.

An approximately linear relationship exists between the monthly mean melt extent for region 2 and the monthly ablation rate for Qamanârssûp sermia (Fig. 6). The agreement is highly significant in June $\left(r^{2}=0.88\right.$,

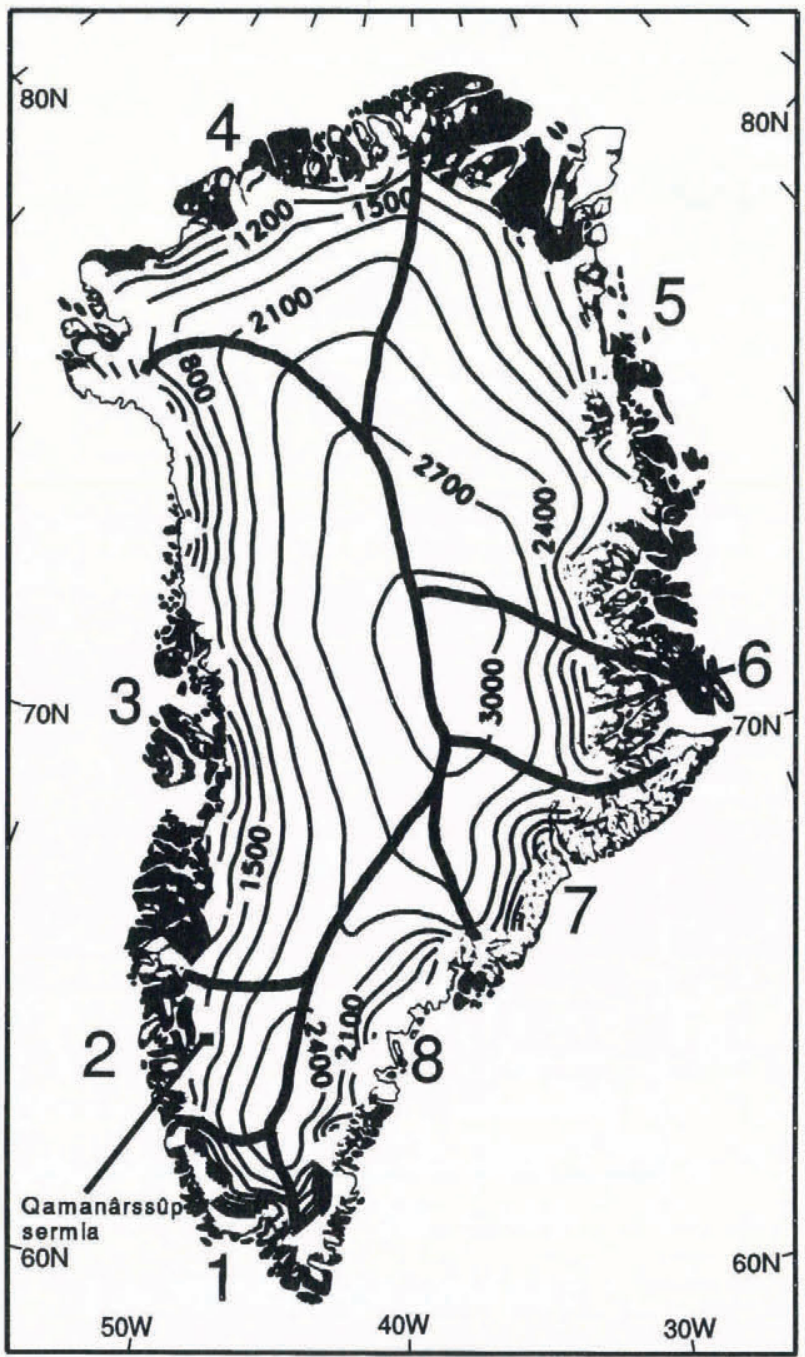

Fig. 5. Eight topographically defined regions of the ice sheet, based on the ice-sheet regions defined by Ohmura and Reeh (1991).

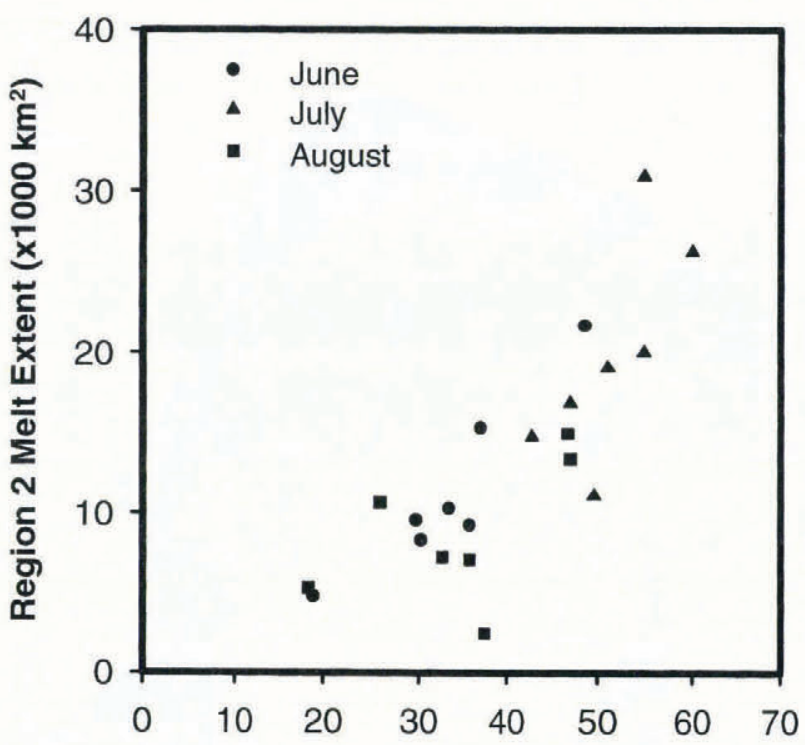

Qamanârssûp sermia Ablation (mm w.e. dy $\left.{ }^{-1}\right)$

Fig. 6. Mean monthly melt-extent values for region 2 of the ice sheet versus stake-ablation rates measured at Qamanârssûp sermia, as given by Braithwaite and Olesen (1990).

significant at $95 \%$ confidence interval), marginally significant in July $\left(r^{2}=0.53\right.$, significant at $90 \%$ confidence interval), but not significant in August $\left(r^{2}=0.31\right)$. The overall agreement was statistically significant $\left(r^{2}=0.66\right.$, significant at $99 \%$ confidence interval). The weaker relationship later in the season is likely the result of an increasingly heterogeneous snowpack. For example, due to the low emissivity of open water, a grid cell containing numerous meltwater ponds and wet snow may have a lower emissivity than is associated with wet snow alone. An increase in the amount of bare ice present in the analysis as the summer season progresses is another reason the relationship is weaker in August. At present, we cannot determine the occurrence of melt on bare ice with the passive-microwave data. Early in the summer, much of the margin of the ice sheet and the outlet glaciers with exposed ice are excluded from analysis by the land mask. As the season progresses, the expanded area of bare ice means that more grid cells containing bare ice are included in the analysis.

Given the linear relationship between the ablation rate and mean melt extent, the same climatic conditions that result in more ice ablation at Qamanârssûp sermia apparently also result in more frequent melt of the snowpack. Braithwaite and Olesen (1989) used the ablation rates at Qamanârssûp sermia as a measure of surface climate on the ice sheet. Therefore, we believe the monthly and seasonal mean melt-extent values can serve as an indicator of climate variation.

In order to gain a better understanding of the spatial variation of melt occurrence, the daily melt extents were examined for extreme events, and the mean annual cycle of melt extent was calculated. The spatial extent of melt was evaluated on a daily basis first, to identify extreme events. The greatest melt extent during the 13 year period occurred on 4 and 5 July 1988. The melt extent reached $735625 \mathrm{~km}^{2}$ on 4 July and $711875 \mathrm{~km}^{2}$ on $5 \mathrm{July}$, 
Table 1. Spatial extent of melt and percentage of ice sheet covered by melt for the $10 \mathrm{~d}$ of most extensive melt during $1979-91$

\section{Date}

Melt extent $\begin{gathered}\text { Melt extent as } \% \text { of } \\ \text { unmasked area }\end{gathered}$
$\mathrm{km}^{2}$

\section{July 1988}

5 July 1988

20 July 1989

15 July 1989

9 July 1988

8 July 1988

5 August 1990

10 July 1991

6 July 1988

26 July 1990

$\begin{array}{ll}735625 & 44.6 \\ 711875 & 43.2 \\ 612500 & 37.2 \\ 606250 & 36.8 \\ 600635 & 36.4 \\ 576875 & 35.0 \\ 576250 & 35.0 \\ 575625 & 34.9 \\ 566875 & 34.4 \\ 563125 & 34.2\end{array}$

covering approximately $44.6 \%$ and $43.2 \%$ of the unmasked area of the ice sheet, respectively. All of the ten days with the greatest melt extent during the 13 years occurred in 1988 or later (Table 1).

The melt-extent values for each day were averaged across the 13 years to produce a mean annual cycle of melt extent. Melt begins to occur in late April, and coverage increases rapidly from mid-May until the maximum coverage occurs in mid-July (Fig. 7). The melt extent decreases rapidly from late July through midAugust, and typically terminates in late September. The

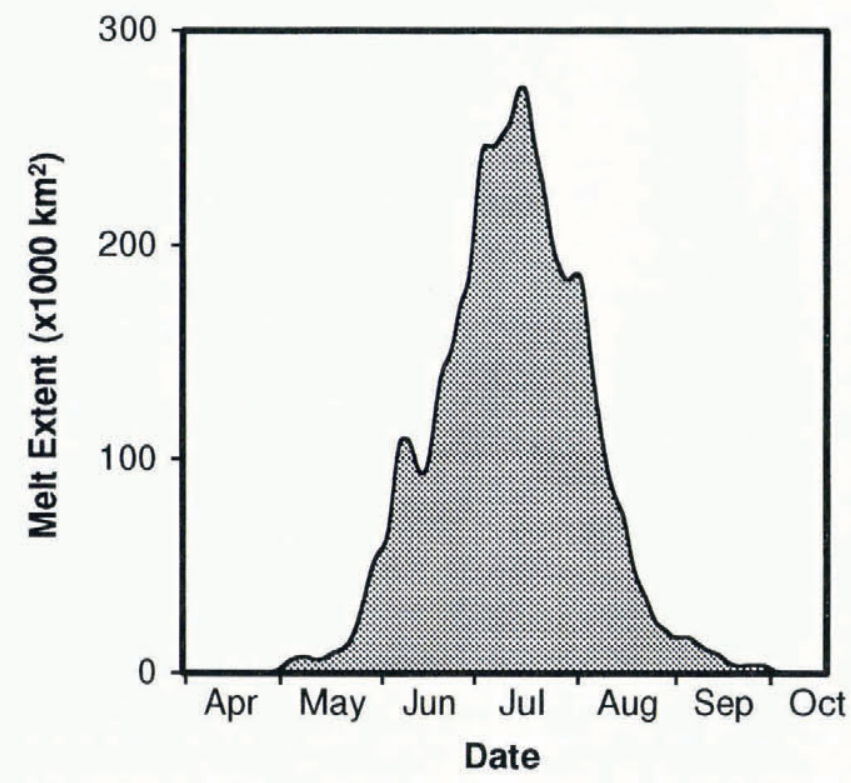

Fig. 7. A time series of the mean daily melt-extent values for the years 197991 demonstrating the typical annual cycle of melt coverage on the ice sheet. time series of daily melt extent for individual years exhibit a large degree of temporal variability; this most likely results from the passage of synoptic-scale weather systems with concomitant changes in the amount of cloud cover and sensible heat advected onto the ice sheet.

In order to understand the spatial variability in melt occurrence, the daily melt-extent values were compiled into a map of the frequency of melt occurrence for each grid cell. The frequency of melt occurrence is defined as the percentage of days on which melt was detected during the 4 month summer period, May-August. The total area classified as melting during at least one day for the 13 years of data includes $1090000 \mathrm{~km}^{2}$, covering approximately $66 \%$ of the unmasked area of the ice sheet. Melt was detected across the south dome of the ice sheet and as high as $3000 \mathrm{~m}$ a.s.l. in a region near $68^{\circ} \mathrm{N}, 37^{\circ} \mathrm{W}$ (Fig. 8). Melt occurred on more than $70 \%$ of the days in MayAugust along the ice sheet's western margin from $67^{\circ} \mathrm{N}$ to $70^{\circ} \mathrm{N}$, but $60 \%$ of the region where melt occurred experienced melt on less than one day in ten (Fig. 8).

The frequency of melt occurrence is probably underestimated. The land mask eliminates some snow surfaces at lower elevations that would likely experience more melt than adjacent locations at higher elevations. Also, daily averaging of the microwave data reduces the ability

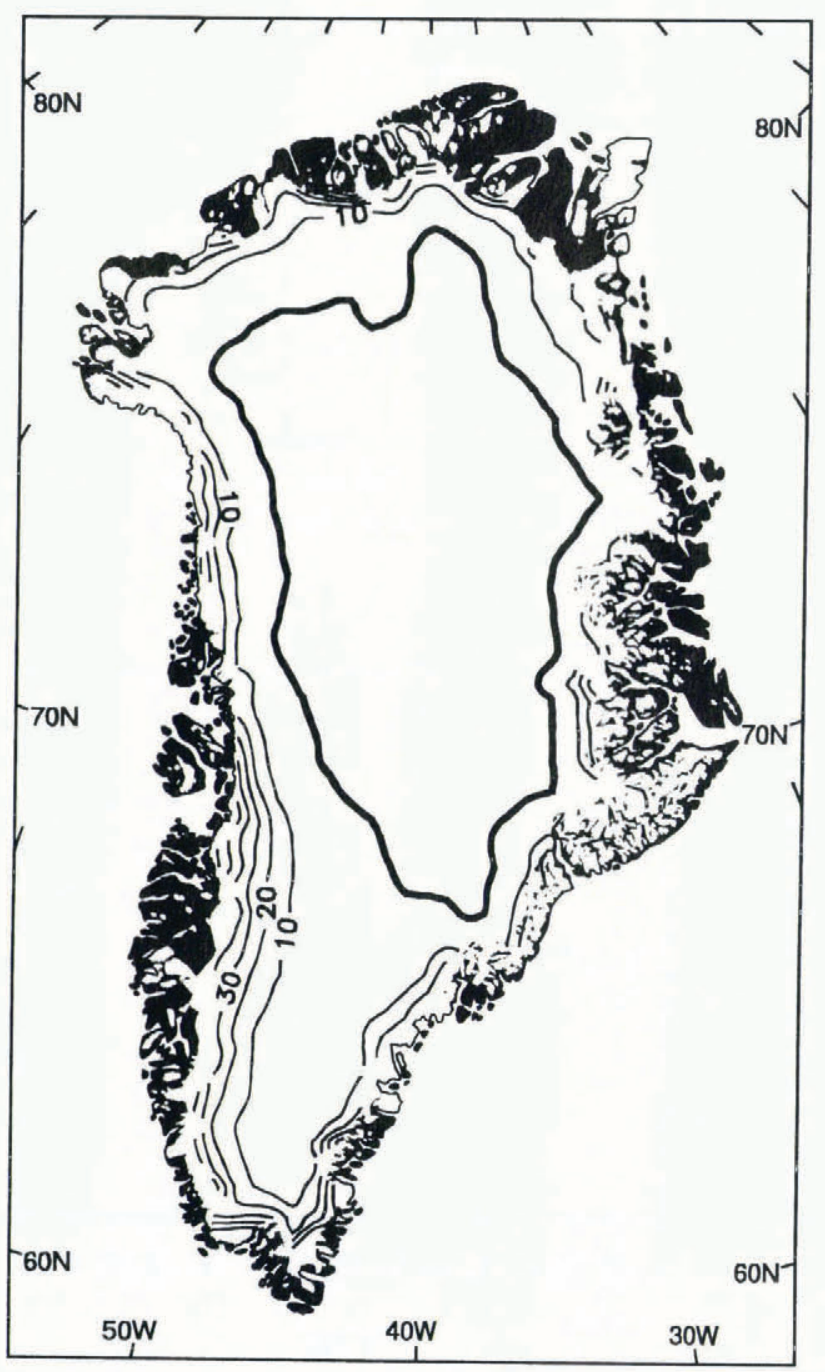

Fig. 8. Percentage of days identified as melting during May-August 197991 from passive-microwave data. 
to identify instances in which melt occurred only during the hours of peak solar radiation or sensible-heat advection. A snowpack that experiences afternoon melt and refreezes in the evening may have a mean daily $T_{\mathrm{B}}$ for the grid cell that does not exceed the threshold value. This may be especially important early and late in the season due to the fewer hours of sunlight. The tendency of refrozen snow to have a lower $T_{\mathrm{B}}$ than fresh snow, due to increased volume scattering from the enlarged grain-sizes, exacerbates this melt-detection problem. Finally, snowpack heterogeneity may cause difficulties in data interpretation with grid cells as large as $625 \mathrm{~km}^{2}$ that may contain a large variation in elevation. A grid cell with both melting and refrozen snow may appear similar to a pixel with fresh snow, reducing the area classified as melting. This being said, the application of a uniform method over the entire time series should still allow the detection of tendencies in melt frequency and extent.

The daily melt-extent values were averaged into monthly and seasonal values to examine the melt-extent time series for inter-annual variations during the 13 year period. The most striking feature of the seasonal meltextent time series (Fig. 9) is the apparent trend of increase in the area of average daily surface melt by approximately $5000 \mathrm{~km}^{2}$ year $^{-1}$. The average value of the daily melt extent for the entire 13 year period is approximately $133000 \mathrm{~km}^{2}$, and the linear trend represents a $3.8 \%$ annual increase. These findings are in general agreement with Braithwaite and others (1992), who suggested that the late 1980 s had higher ablation rates than the early to mid-1980s. The 5 years of SSM/I data (1988-91) have a mean seasonal melt area $26 \%$ greater than the 8 years of SMMR data (1979-87). Contrary to evidence from the sensor-overlap period, it is still possible that the sensor change has contributed to some of the increase in detected melt area. However, the SMMR data alone have a positive trend of about $2500 \mathrm{~km}^{2}$ year ${ }^{-1}$ in average daily melt area. (The year 1987 is included as a SMMR year because SMMR data are used from May through July to calculate the seasonal average; SSM/I data are used only

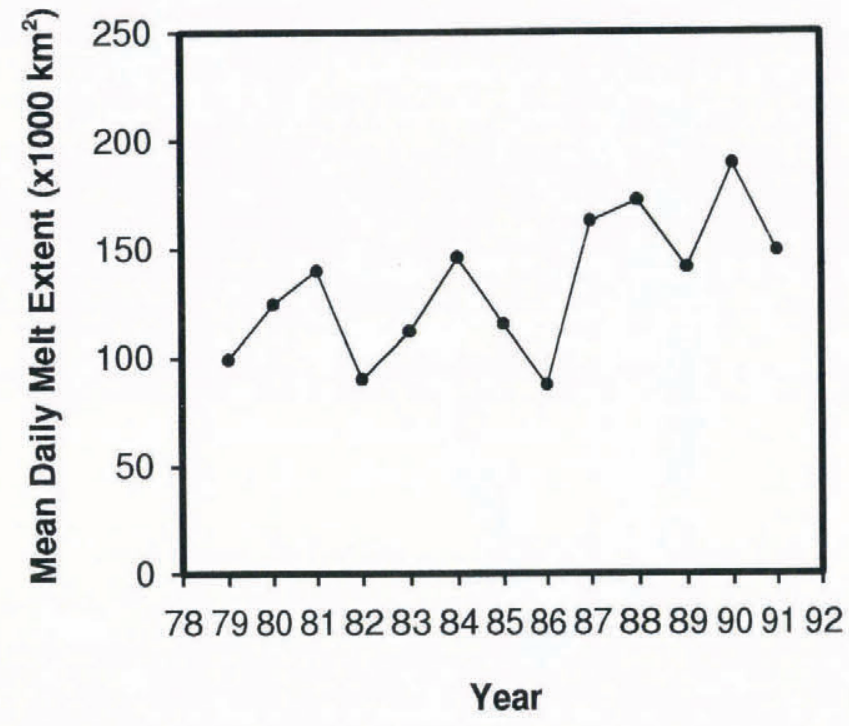

Fig. 9. Seasonal (May-August) averages of the daily melt extent as identified with passive-microwave data. in August.) All four summer months exhibited an increase in melt extent, with the most substantial increases in July and August (Fig. 10). July has a positive trend of nearly $8200 \mathrm{~km}^{2}$ year $^{-1}$, compared to approximately 5500, 5400 and $1200 \mathrm{~km}^{2}$ year $^{-1}$ for August, June and May, respectively. Expressed as a percentage of the 13 year mean, August has the most positive trend, possibly indicating a longer melt season. June has the greatest variability in melt extent, from a low value of $69800 \mathrm{~km}^{2}$ average daily melt extent during the 1979 summer season to a high of $283900 \mathrm{~km}^{2}$ in 1987.

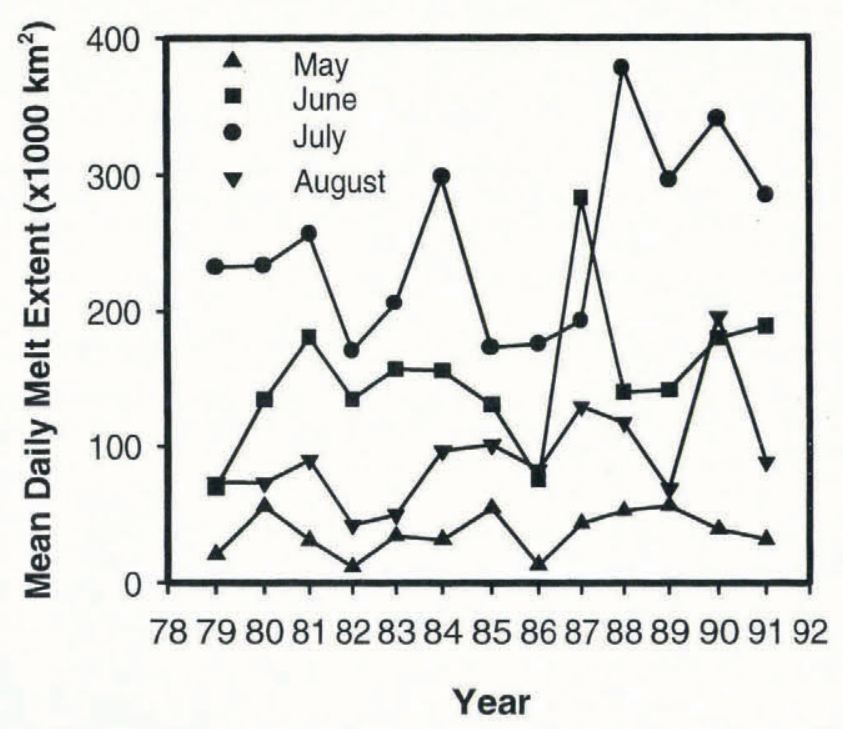

Fig. 10. Monthly averages of the daily melt extent as identified with passive-microwave data.

Examining the seasonal mean melt extents for each region, regions 2 and 3, which cover most of the western half of the ice sheet, each show a statistically significant increase. The northerly regions, 4 and 5, show a slight trend toward increasing melt, but neither is significant. The melt-extent time series for the three southeastern regions, 6-8, remain relatively flat. In fact, region 7 shows a small, though statistically insignificant, trend toward decreasing melt over the 13 year period.

Region 3, the largest of the eight regions and the one with the greatest mean melt extent (Table 2), has the largest trend in melt extent with a $6.7 \%$ annual increase (significant at the $99 \%$ confidence level). Region 2, located just south of region 3, showed a $4.2 \%$ annual increase over the 13 years (significant at the $99 \%$ confidence level). Regions 1 and 2, in the southwest, have the greatest percentage of area covered by melt, $24.4 \%$ and $17.2 \%$, respectively (Table 2 ). The northeastern regions, 5 and 6 , have the smallest percentage of mean daily seasonal-melt coverage, each at $5.3 \%$. Monthly trends were examined for the two regions with significant seasonal trends. Region 2 had an increase of $900 \mathrm{~km}^{2}$ year $^{-1}$ (significant at the $95 \%$ confidence interval) in July and $500 \mathrm{~km}^{2}$ year ${ }^{-1}$ (significant at the $90 \%$ confidence interval) in August. Region 3 had an increase of $3000 \mathrm{~km}^{2}$ year ${ }^{-1}$ (significant at the $90 \%$ confidence interval) in July and $4900 \mathrm{~km}^{2}$ year ${ }^{-1}$ (significant at the $95 \%$ confidence interval) in August. The trends for 
both May and June were insignificant for regions 2 and 3 .

Overall, the trend of increasing mean melt area, analogous to increasing melt frequency, is confined to the southwest and west of the ice sheet, primarily late in the season. Because a large proportion of the total melt of the ice sheet occurs in these regions, the mean annual melt extent for the entire ice sheet also shows a positive trend.

Table 2. May-August mean melt area and per cent coverage for each of the eight topographically defined regions (within land/water mask)

\begin{tabular}{|c|c|c|c|c|}
\hline \multirow[t]{2}{*}{ Region } & \multirow{2}{*}{ Total area } & \multirow{2}{*}{$\begin{array}{c}\text { Mean melt } \\
\text { extent } \\
\mathrm{km}^{2}\end{array}$} & \multirow[t]{2}{*}{$\begin{array}{l}\text { Mean melt } \\
\text { extent as \% of } \\
\text { unmasked area }\end{array}$} & $\begin{array}{c}\text { Mean eler- } \\
\text { ation }\end{array}$ \\
\hline & & & & m a.s.l. \\
\hline 1 & 51250 & 12500 & 24.4 & 1633 \\
\hline 2 & 69375 & 11900 & 17.2 & 2140 \\
\hline 3 & 539375 & 45000 & 8.3 & 2240 \\
\hline 4 & 221875 & 15000 & 6.8 & 1768 \\
\hline 5 & 410625 & 21600 & 5.3 & 2046 \\
\hline 6 & 105000 & 5600 & 5.3 & 2551 \\
\hline 7 & 90000 & 7000 & 7.8 & 2333 \\
\hline 8 & 160625 & 14400 & 9.0 & 2222 \\
\hline Total & 1648125 & 133000 & 8.0 & 2128 \\
\hline
\end{tabular}

\section{SUMMARY AND CONCLUSION}

A threshold value of $37 \mathrm{GHz}$, horizontally polarized $T_{\mathrm{B}}$ has been used to identify areas of melt on the Greenland ice sheet for 1979 91. By merging the data sets of two satellite microwave radiometers, a record of high spatial and temporal resolution of melt occurrence on the ice sheet has been developed. An examination of this detailed record provides evidence of a trend toward increasing seasonally averaged daily melt extent of about 3.8\% annually. All four months examined, May-August, demonstrate a positive trend in melt coverage from 1979 to 1991, but the months of July and August account for approximately $70 \%$ of the seasonal trend. However, the agreement between the mean monthly-melt extents and the measured ablation rates is weakest late in the summer season (July and August) when the trends are statistically most significant. Therefore, one must exercise caution in interpreting the melt-extent time series as indicative of increasing melt frequency or melt extent. Additionally, the apparent increase in mean melt extent is confined to the west and southwest of the ice sheet.

The loss of data near the margin of the ice sheet and the problems of diurnal variations of melt occurrence and spatial variations within a grid cell likely result in a bias toward identification of less melt than actually occurred. However, the relative melt-frequency values on a monthly and seasonal basis will prove useful in comparison to surface observations of ablation rates. These results should be used in conjunction with detailed surface meteorological observations to determine the usefulness of the passive-microwave satellite data in mass-balance studies. Continued monitoring of melt occurrence on the Greenland ice sheet is of particular value given the ongoing debate concerning global climate change. Recorded changes in melt frequency or total coverage should prove a powerful indicator of climate change in the Arctic.

\section{ACKNOWLEDGEMENTS}

The authors thank S. Ekholm and the Danish National Survey and Cadastre for providing the elevation data for Greenland from the ERS-1 radar altimeter. We also thank Dr R. Braithwaite and K. Kuivinen for their useful comments on the surface conditions on the Greenland ice sheet. Additionally, we thank Dr Braithwaite, Dr M. Palecki and an anonymous reviewer for their many constructive editorial comments on the manuscript. The SMMR and SSM/I gridded brightness-temperature data on CD-ROM were obtained from the National Snow and Ice Data Center, Boulder, CO, U.S.A. This work was supported by NASA training grant NGT-30127 and NASA grant NAGW-1266.

\section{REFERENCES}

Abdelrazik, M., F. Ulaby and H. Stiles. 1981. A model describing the microwave emission from a multi-layer snowpack at $37 \mathrm{GHz}$. Greenbelt, MD, Goddard Space Flight Center. (NASA CR-16708.)

Bindschadler, R.A. 1985. Contribution of the Greenland ice sheet to changing sea level: present and future. In United States Department of Energy. Glaciers, lie Sheets, and Sea Levels: Effect of a $\mathrm{CO}_{2}$-induced Climatic Change. Report of a Workshop held in Seatlle, Washington, September 13-15, 1984. Washington, DC, National Academy Press, 258-266.

Bindschadler, R. A., H.J. Zwally, J. A. Major and A. C. Brenner. 1989 Surface topography of the Greenland ice sheet from satellite radar altimetry. Washington, DC, National Aeronautics and Space Administration. (NASA SP-503.)

Braithwaite, R.J. and O.B. Olesen. 1989. Detection of climate signal by inter-stake correlations of annual ablation data, Qamanârssûp sermia, West Greenland. J. Glaciol., 35(120), 253-259.

Braithwaite, R.J. and O.B. Olesen. 1990. A simple energy-balance model to calculate ice ablation at the margin of the Greenland ice sheet. J. Glaciol., 36(123), 222-228.

Braithwaite, R.J., O.B. Olesen and H. H. Thomsen. 1992. Calculated variations of annual ice ablation at the margin of the Greenland ice sheet, West Greenland, 1961-90. 7. Glaciol., 38(129), 266-272.

Budd, W.F., T. H. Jacka, D. Jenssen, U. Radok and N. W. Young. 1982. Derived physical characteristics of the Greenland ice sheet. Parkville, Victoria, University of Melbourne. Meteorological Department. (Publication 23.)

Chang, A. T. C., P. Gloersen, T. Schmugge, T. T. Wilheit and H.J. Zwally. 1976. Microwave emission from snow and glacier ice. $\vec{J}$. Glaciol., 16(74), 2329.

Chang, A. T. C., J. L. Foster, M. Owe, D. K. Hall and A. Rango. 1985. Passive and active microwave studies of wet snowpack properties. Nord. Hydrol., 16 2), 57-66.

Foster, J. L., D. K. Hall, A. T. C. Chang and A. Rango. 1984. An overview of passive microwave snow research and results. Rev. Geophys. Space Phys., 22(2), 195208.

Gloersen, P. and L. Hardis. 1978. The Scanning Multichannel Microwave Radiometer experiment. In Madrid, C., ed. The Nimbus7 user's guide. Washington, DC, National Aeronautics and Space Administration.

Gloersen, P., T. T. Wilheit, T. C. Chang, W. Nordberg and W.J. Campbell. 1974. Microwave maps of the polar ice of the Earth. Bull. Am. Meteorol. Soc., 55(12), 14421448.

Hofer, R. and C. Mätzler. 1980. Investigations on snow parameters by 
radiometry in the 3- to $60-\mathrm{mm}$ wavelength region. 7. Geophys. Res., $85(\mathrm{Cl}), 453460$.

Hollinger, J., R. Lo, G. Poe, R. Savage and J. Pierce. 1987. Special sensor microwavelimager user's guide. Washington, DC, Naval Research Laboratory.

Jezek, K.C. and 6 others. 1991. Comparison between SMMR and SSM/I passive microwave data collected over the Antarctic ice sheet. Byrd Polar Research Center. Technical Report 91-03.

Kunzi, K. F., S. Patil and H. Rott. 1982. Snow-cover parameters retrieved from Nimbus-7 Scanning Multichannel Microwave Radiometer (SMMR) data. IEEE Trans. Geosci. Remote Sensing, GE-20(4), 452467.

Mote, T. L., M. R. Anderson, K. C. Kuivinen and C. M. Rowe. 1993. Passive microwave-derived spatial and temporal variations of summer melt on the Greenland ice sheet. Ann. Glaciol., 17, 233-238.

National Snow and Ice Data Center. 1992. DMSP SSM I brightness temperature grids for the polar regions on CD-ROM. Users' guide. Boulder, CO, National Snow and Ice Data Center.

Ohmura, A. and N. Reeh. 1991. New precipitation and accumulation maps for Greenland. F. Glaciol., 37(125), 140-148.

Peltier, W. R. and A. M. Tushingham. 1989. Global sea level rise and the greenhouse effect: might they be connected? Science, $\mathbf{2 4 4}$ (4906), 806-810.

Rotman, S. R., A. D. Fisher and D.H. Staelin. 1982. Inversion for physical characteristics of snow using passive radiometric observations. F. Glaciol., 28 (98), 179-185.

Stephenson, P.J. 1967. Some considerations of snow metamorphism in the Antarctic ice sheet in the light of ice crystal studies. In Ôra, H. ed. Physics of snow and ice. International Conference on Low Temperature Science ... 1966, Sapporo, Japan. Proceedings. Volume I, Part 2. Sapporo,
Hokkaido University. Institute of Low Temperature Science, 725740 .

Stiles, W. H. and F. T. Ulaby. 1980. The active and passive microwave response to snow parameters. 1. Wetness. 7. Geophys. Res., 85(C2), 1037-1044.

Thomas, R. H. and 8 others. 1985. Satellite remote sensing for ice sheet research. Washington, DC, National Aeronautics and Space Administration. (NASA Tech. Memo. 86233.)

Tinga, W. R., W.A.G. Voss and D.F. Blossey. 1973. Generalized approach to multiphase dielectric mixture theory. 7. Appl. Phys., 44 (9), 3897-3902.

Tiuri, M. and H. Schultz. 1980. Theoretical and experimental studies of microwave radiation from a natural snowfield. In Rango, A., ed. Microwave remote sensing of snowpack properties. Proceedings of a workshop ... Fort Collins, Colorado, May 20-22, 1980. Washington, DC, National Aeronautics and Space Center, 225 234. (Conference Publication 2153.)

Ulaby, F. T. and W.H. Stiles. 1980. The active and passive microwave response to snow parameters. 2. Water equivalent of dry snow. 7 . Geophys. Res., 85(C2), 1045-1049.

Ulaby, F. T., R. K. Moore and A. K. Fung. 1986. Microwave remote sensing: active and passive. Vol. 3. Reading, MA, Addison-Wesley Publishing Co.

Weidick, A. 1985. The ice cover of Greenland. København, Grønlands Geologiske Undersøgelse. (Gletscher-Hydrologiske Meddelelser $85 / 4$.

Zwally, H.J. 1977. Microwave emissivity and accumulation rate of polar firn. F. Glaciol., 18 (79), 195-215.

Zwally, H.J. 1989. Growth of Greenland ice sheet: interpretation. Science, 246(4937), 1589-1591.

MS received 26 fuly 1993 and in revised form 16 March 1994 